\title{
HERA AS PROTECTRESS OF MARRIAGE, CHILDBIRTH, AND MOTHERHOOD IN MAGNA GRAECIA
}

\begin{abstract}
Summary: This paper is aimed to analyze several different aspects of the cult of Hera in Magna Graecia - from the Archaic to the Hellenistic period - where the goddess was already worshipped since the foundation of most ancient colonies in southern Italy. By examination both of the ancient Greek sources and the archaeological evidences, we tried to outline the features and the duties of the goddess over time, also comparing all the detected data with the Greek world. The result will perhaps help in defining them better than has been done hitherto.
\end{abstract}

Key words: Magna Graecia, cult of Hera, Heraion of Foce Sele (Poseidonia), Achaean colonies, marriage, childbirth, motherhood

\section{INTRODUCTION (C.M.M.)}

Taking part in the panel "Which Maternity for Hera/Juno? Myths and Cults between Greece, Magna Graecia and Rome", offered us the opportunity to reflect, although in preliminary fashion, on the aspect of Hera as patroness of women and her role in watching over the phases of transition to matrimony and procreation in the Greek world and in Magna Graecia through a discussion of the ancient Greek sources and archaeological evidence.

In some of the main sanctuaries dedicated to the goddess in the Greek world (Perachora, Argos, Samos and Tiryns), the nature of the offerings, in particular the coroplastics, suggests these were cults centred on fertility, which Hera supervised as queen and patroness of the citizens. She assumed the function of the guardianship of matrimony, of which she is known as the "custodian of the keys", ${ }^{1}$ and of all consequent

${ }^{1}$ Aristoph. Thesm. 973-976. 
moments. The statuettes of Hera and Zeus seated on a single throne ${ }^{2}$ are a reference to the royal sacred conjugal union "mythical and ritual model of monogamous marriages". They are Hera Teleia and Zeus Teleios, "Masters of the House", the couple that protected the marital union and which, through religious ceremonies sanctioning marriage, guaranteed the nuptial rites, with their consent sealing the union's validity in society. Indeed, for the Greeks matrimony was of the utmost importance, expressing attainment of maturity for both sexes, as defined in the religious context by Hera Teleia, providing the necessary foundation for the procreation of legitimate offspring and for the perpetuation of civil society. From this point of view, the context and reasoning behind the dedication to the goddess expressed in an epigram from the Palatine Anthology, ${ }^{5}$ clarifying why the young bride-to-be, Alcibia, would have "dedicated the veil from her hair to Hera, when she entered into lawful marriage."

The idea that marriage and fertility were the fulfilment of a woman's nature is clearly represented by the female games held at Olympia every four years. ${ }^{6}$ As part of this celebration, held in honour of Hera (the Heraia), the parthenoi took part in sport and musical competitions, both opposite and complementary to the male competitions at the Olympics. Pausanias ${ }^{7}$ offers detailed evidence of these games and also cites the aition, suggesting a mythical-religious and historical motivation. In fact, he states that the running races in which the parthenoi participated were said to date back to very ancient times, that is to when Hippodamia founded them in thanks to Hera for her marriage to Pelops. Furthermore, the creation of a college of sixteen priestesses is also ascribed to Hippodamia, together with whom she celebrated the Heraia for the first time. Within this context, the attainment of marriage seems to be the dominant motive, indicated as a remedy to the "wild" chaos of the female condition outside the functions of wife and mother. The maidens' race, in which participation is a rite of passage, seems to have been inspired by two important models for women to aspire to in their later life. First, was Hera the bride par excellence and second was Hippodamia, ${ }^{8}$ a mortal woman of high rank elevated to the status of heroine, thanks to the divine privilege she enjoyed during life and her complete fulfilment of a woman's functions. ${ }^{9}$

The objective behind the rituals for the transition of status undertaken by the nymphè before becoming a wife and mother was to ask the goddess for protection and assistance, during the delicate moment when young girls moved into the world of sexual maturity and procreation, as required within the context of traditionally coded roles. In this sense, a good example is represented by another epigram, ${ }^{10}$ in which a husband-to-be gives an embroidered veil as a wedding present to his future bride, ask-

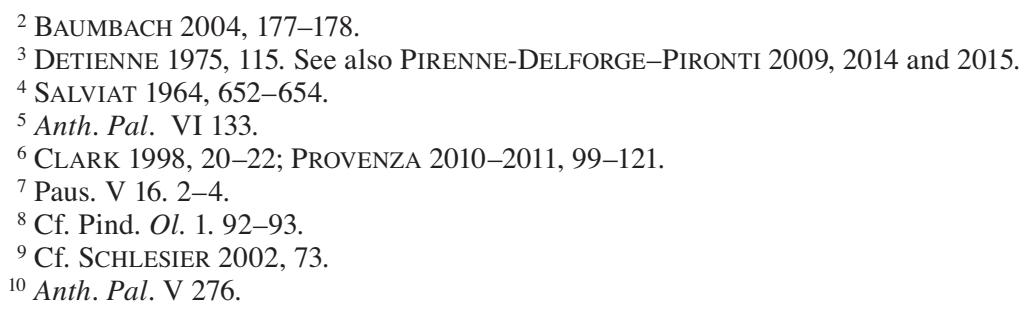


ing her to wear it "as would a virgin, who looks to the marriage bed and a rich flowering of offspring". If the woman did this, he would give her an even richer gift - a cap encrusted with jewels - for having responded 'correctly' to what was required in her role as a bride. Thus, it is clear that in order for the transition of status to be completed Greek society required the bride to provide offspring, and this necessitated asking for divine help. Hera, patroness of women in the part that they played in the social community, watched over feminine life in all its phases, and in particular the transition to marriage and procreation. In this regard, for a long time it was thought that the direct function of maternity was denied Hera, who in many Greek myths is described as childless. The moments of birth and growth that are functional to the $\tau \dot{\varepsilon} \lambda$ os and perpetuation of the polis, are, however, occasions for religious practices, of which archaeological traces remain, in honour of this goddess. Assistance during labour, for example, is documented in primis in the literary sources, although references are scant:

"Ambrosia freed from the bitter pains of the birth, placed, Illizia, at your glorious feet the binding for my hair and the peplos I wore when, in the tenth month, I gave birth to twins from my heavy womb". 11

Illizia, the goddess who watched over childbirth and interceded to bring it to a happy conclusion (whether this divinity was distinct from Hera or could be assimilated with her) was turned to by the puerperae during the delicate phases of childbirth, and was thanked with offerings of gifts, both personal and otherwise, for its happy conclusion. In the sanctuaries dedicated to Hera, archaeological research has revealed the presence of terracottas representing a pregnant woman or woman close to giving birth, which have been rightly associated with this specific competence of the goddess. A fragment of a hand-sculpted statuette, datable to between the $7^{\text {th }}$ and $6^{\text {th }}$ centuries $\mathrm{BC}$, depicting the bust of a woman with a prominent belly, ${ }^{12}$ was found in the sanctuary of Argive Hera. As suggested by Waldstein and Chase, ${ }^{13}$ the presence of this subject in the sanctuary of Argive Hera must relate to the function she assumed as protectoress of childbirth. A comment written by Hesychius in the $5^{\text {th }}$ century AD, referring to Illizia as "Hera of Argos", confirms this suggestion. ${ }^{14}$ While there are doubts about who the statuette depicts (whether Hera herself or, more probably, the woman making the offering), about the occasion when she was made, Chase and Waldstein state with some degree of certainty that it was "an appropriate votive offering for a pregnant woman or for one hoping for pregnancy". 15

Two miniature beds were found among the artifacts from the sanctuary of Hera at Argos, one of terracotta and the other of bronze, dated respectively by Strøm to the $7^{\text {th }}-6^{\text {th }}$ centuries BC and to between the late Archaic period and the early Classical period. ${ }^{16}$ The presence of the beds as votive offerings takes on a specific significance when associated with a story narrated by Pausanias, who cites a kline "of Hera"

\footnotetext{
11 Anth. Pal. V 200.

12 JENKINS 1931-1932, 24.

${ }^{13}$ Chase-Waldstein 1905, 30, n. 124.

${ }^{14}$ Hsch. s.v. Eíd $\varepsilon ı \theta v i ́ \alpha \varsigma$.

${ }^{15}$ Chase-Waldstein 1905, 30, n. 124.

16 STRØM 1988, 88.
} 


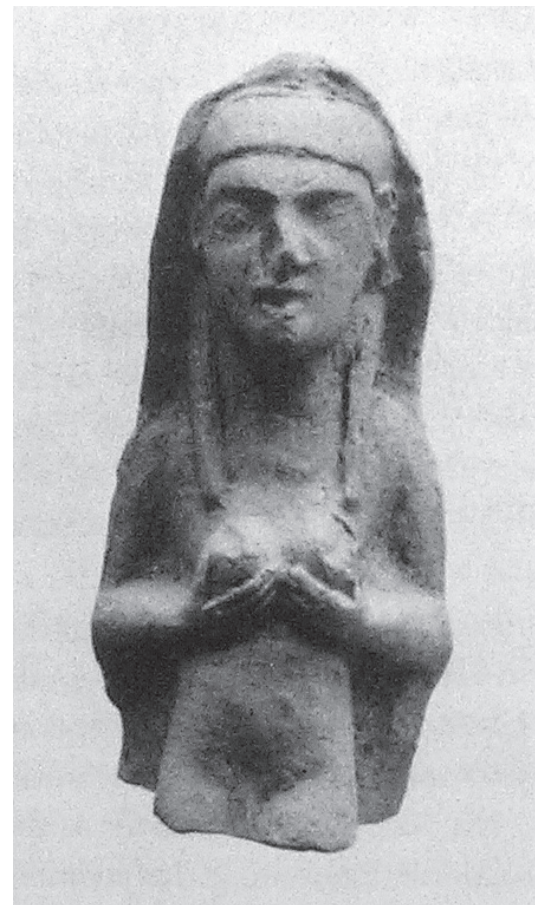

Fig. 1. Samos, Heraion. Terracotta female figurine holding both her hands to her breasts. $7^{\text {th }}$ century BC

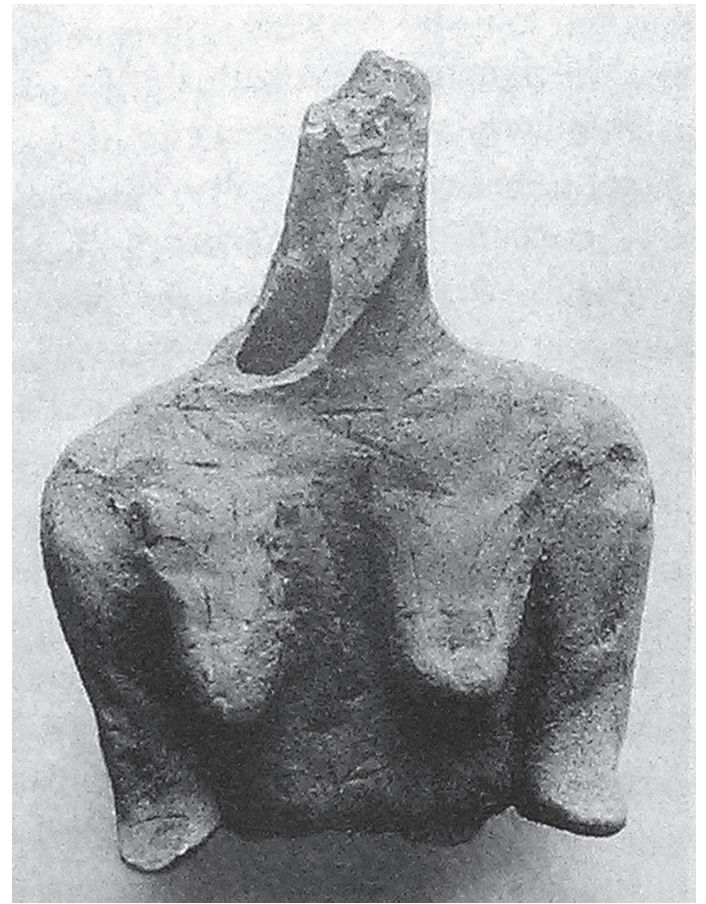

Fig. 2. Perachora, Heraion. Terracotta nude female figurine with prominent breast. Probably $8^{\text {th }}$ century BC (BAUMBACH 2009, p. 21, fig. 2.19) (BAUMBACH 2009, p. 155, fig. 6.18)

in the pronaos of the Classical temple dedicated to her, ${ }^{17}$ and with the comment by Hesychius, referring to a particular type of sacrifice in honour of Argive Hera called

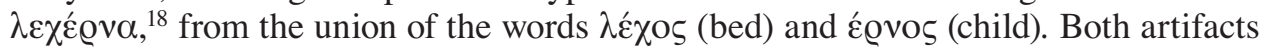
could allude to the concept of the cradle and thus to birth, depicted by the two miniature beds. ${ }^{19}$ Finally, according to the Suda, one of the cult statues at the sanctuary of Argos presented a pair of bronze scissors. ${ }^{20}$ Baumbach states that, as scissors were also used to cut the umbilical cord, the image depicts the goddess as an obstetrician and once again links her to the concept of the divinity watching over labour and births. ${ }^{21}$

\footnotetext{
${ }^{17}$ Paus. II 17. 3.

${ }^{18}$ Hsch. s.v. $\lambda \varepsilon \chi \varepsilon \dot{\varrho} v \alpha$.

${ }^{19}$ BAUMBACH 2004, 80-81.

${ }^{20}$ Sud. s.v. "H@ $\alpha$.

${ }^{21}$ BAUMBACH 2004, 81 with bibliography.
} 
Seven faience perfume holders from the Heraion at Samos, dating to about the $7^{\text {th }}$ century BC, are more difficult to interpret. They are in the form of a kneeling female figure with an infant on her back and holding an ibex between her hands. ${ }^{22}$ These artefacts are of Rhodian and Egyptian production and, although depicting a nomadic woman, (attested by the child carried on the back, according to Baumbach), ${ }^{23}$ they may have acquired another meaning in the Greek context. The presence of the infant and the kneeling position, typical of the birthing position in ancient Greece, ${ }^{24}$ would have made these statuettes suitable for being offered by a woman "who turned to Hera in her function as protectress of childbirth".

Finally, Hera is also kourotrophos. The images provided by coroplastics attributable to this particular function of the goddess, are principally of two types recorded both in Greece and Magna Graecia from the late $7^{\text {th }}$ century BC to at least the $5^{\text {th }}$ century BC. In some the female subject is shown, naked or dressed, with both hands resting on the breasts (fig. 1); others depicting a woman holding a child in her arms. On the one hand, scholars are rightly reluctant to attribute a definite identity to the subjects depicted by the coroplastics (whether Hera herself or an offerer); on the other hand, their presence in all the main Heraia (Perachora, Argos, Samos and Tiryns) confirms the kourotrophic aspect of the goddess. As regards the first type, it has been noted how the act of clutching the hands to the breasts is considered a symbol of fertility typical of the East, and in particular of Astarte. ${ }^{25}$ Even if, for the Greeks, Astarte could be assimilated with Aphrodite, the gesture could have other meanings: as suggested by Böhm, ${ }^{26}$ in the votive contexts of the Heraia, it does not imply a concept of abundance, but instead alludes to the practice of breastfeeding. A terracotta bust from Perachora may also allude to the latter (fig. 2); the breast is prominent and deliberately emphasized because, perhaps swollen with milk, it may represent a mother about to nurse her infant. ${ }^{27}$ In the case of the terracottas of women holding an infant, their presence is rather a reference to the incarnation of the desire for legitimate offspring for which Hera, by ensuring in some cases nutriment, in others protection, guarantees the growth and therefore the perpetuation of society. It is possible to link some faience examples of Isis seated and nursing the infant Horus, from the sanctuaries of Perachora ${ }^{28}$ and Samos, ${ }^{29}$ to this iconography. These artifacts, produced in Rhodes and Egypt and datable to the $7^{\text {th }}$ century BC, form "an appropriate dedication to Hera not just because of the nursing scene itself but also because, like Hera at Perachora and in other sanctuaries, Isis was also regarded as responsible for mothers and children".

\footnotetext{
22 WeBB 1978, 27, nos. 122-125; KiliAN-DiRLMEIER 1985, 242.

23 BAUMBACH 2004, 154-155.

${ }^{24}$ STOOP 1960, 24-35; BINDER 1976, 89-90.

25 ВÖнм 1990, 129.

${ }^{26}$ BÖHM 1990, 137.

${ }^{27}$ PAYNe 1940, 66, n. 304; Morgan 1999, 404.

${ }^{28}$ DUNBABIN 1962, 196 and 242.

${ }^{29}$ WeBB 1978, 100, n. 605, 605 bis, 607-612.
} 


\section{HERA AS PROTECTRESS OF MOTHERHOOD IN MAGNA GRAECIA: THE SANCTUARY OF HERA AT THE MOUTH OF SELE RIVER (POSEIDONIA-PAESTUM) (M.G.)}

I will personally focus on the sanctuary of Hera at the mouth of the Sele River, since it is the most important and impressive witness of the role of Hera as protectress of motherhood in Magna Graecia.

The cult of Hera was imported in Poseidonia-Paestum by Achaeans from the Peloponnese. Legend has it that the Argonauts, led by Jason in their adventuresome wanderings across rivers and distant lands along the route of metals, spread her cult, founding cities and sanctuaries dedicated to her. It was one such mythical tradition that accounted for the founding of the sanctuary of Hera at the mouth of the Sele River; the goddess was to be worshipped with the title Argonia, which recalls both her Argive origin and the protection afforded to Jason's ship, the swift Argo. In Archaic period the goddess Hera was revered as the protectress of fertility: a flower, a child, an animal, a necklace, and a pomegranate were her attributes - or as a girl, a virgin with weapons. Only in the Lucanian period did she become the protectress of marriage and then she had also a clear funeral value. She was represented wrapped in a cloak with her head covered and a veil, seated on a throne, with her attributes being the pomegranate, her staff or a basket of fruit.

In Poseidonia-Paestum, the Hera cult is recorded both in the extra-urban sanctuary at the mouth of Sele river and in the urban Southern sanctuary. This double presence emphasizes the leading role of the goddess within the Poseidonian pantheon; she plays the same role in Kroton, Metaponto and Sybaris as well. This leadership comes from her being essentially a polyadic goddess with many polyvalent features. ${ }^{30}$

The worship of Hera in the Western Greek Achaeans towns is strictly related to her Peloponnesian worship.

According to Strabo (VI 1. 1), at the mouth of Sele river, Hera was worshipped as Argonia and the sanctuary there was founded by Jason and Argonauts. The Greek colonists would therefore have decided to connect the Sele extra-urban sanctuary with the Argonauts' saga, with their journey towards the Western Mediterranean, and with the fluvial and land routes they had followed. The ship itself, the Argo, was also protected by the Argonautic Hera. The sanctuary on the northern boundary of ancient Poseidonia's chora was consecrated to this goddess, who had followed and protected the Argonauts throughout their journey. ${ }^{31}$ Consequently, the religious and cultic organization of the new Achaean colony is based on the presence and the role of the Argonautic Hera, but the goddess seems to have had different features in the urban and extra-urban sanctuaries in her honour. ${ }^{32}$

In Poseidonia, as well in Metaponto, Hera was associated with Apollo, while, in the extra-urban sanctuary at the mouth of Sele river, she is also associated, in addition

${ }^{30}$ GRECO 2010, 556.

${ }^{31}$ MELE 1992, 618-621.

${ }^{32}$ CipRIANi 1997, 211-225; CIPRIANi 2012, 27-169. 
to Apollo, with Heracles and Achilles, as we can see on the archaic carved metopes. Heracles and Achilles remind us of all the values and meanings that coming-of-age initiation rites had in Ancient Greek religion. ${ }^{33}$

\subsection{The role of Hera in the sanctuary at the mouth of the Sele river}

Discovered on April $9^{\text {th }} 1934$ by Paola Zancani and Umberto Zanotti Bianco, this sanctuary was founded in the early decades of the $6^{\text {th }}$ century BC by a group of Achaeans from Sybaris. ${ }^{34}$ Today it lies approximately $1500 \mathrm{~m}$ from the mouth of the river because of bradyseism, which in the plain of Paestum has pushed the coastline nearly two miles out to sea (figs 3-4).
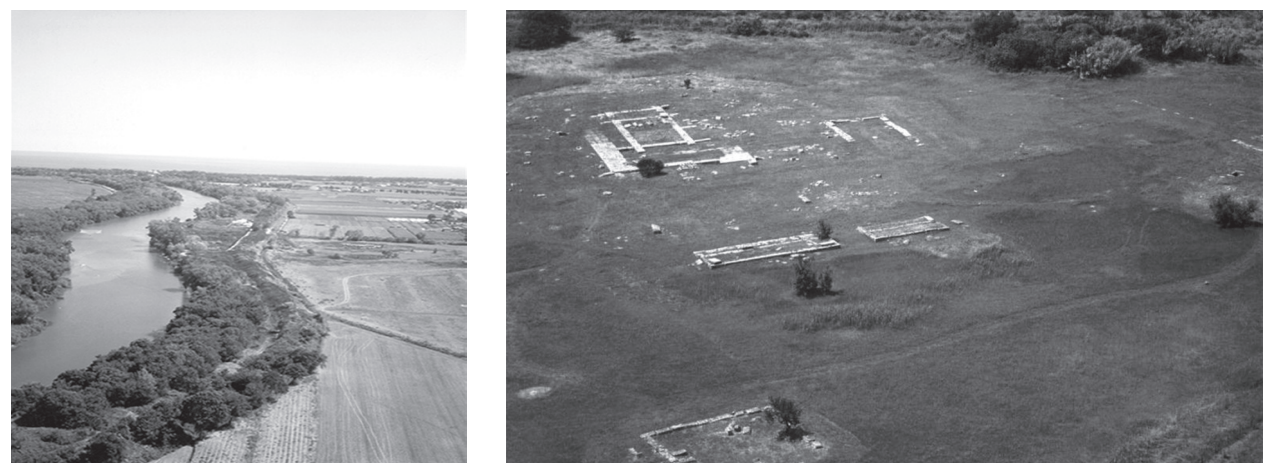

Figs 3-4. Poseidonia, the sanctuary of Hera at the mouth of the Sele river. Aerial view

(Department of Humanistic Studies - University of Naples Federico II)

The sanctuary is situated on the northern boundary of the Ancient Poseidonia's territory, on the left bank of the river, about $9 \mathrm{~km}$ away from the city itself. North of the river stretched the vast fertile plain from Eboli to Fratte near Salerno, which was firmly occupied by the Etruscans, whose wealthy, powerful centre was in Pontecagnano. The river was a frontier zone across which the two cultures, Greek and Etruscan, faced and met each other, weaving complex, frequent relations.

The sanctuary of Hera performed several functions, ranging from a meeting-point and trading-post to a site of political self-representation and social integration where rites were performed to initiate young people into city life. Although today

${ }^{33}$ Masseria-Torelli 1999, 205-262; GreCo 2010, 565-567; GreCO 2012, 233-236.

34 The study of the sanctuary of Hera at the mouth of Sele River, under the scientific direction of Giovanna Greco and Juliette de La Genière, and in collaboration with the Archaeological Superintendence of Salerno, is part of an important research programme that the University of Naples Federico II has been carrying out since 1987. This study is a part of the research project focused on the resuming of archaeological excavations in the sacred area and on the analysis and cataloguing of the first materials found by P. Zancani and U. Zanotti Bianco in the mid-20 ${ }^{\text {th }}$ century (1934-1963). The last results are published by J. de La Genière and G. Greco in two volumes of the series Atti e Memorie della Societa Magna Grecia in 2010, see LA GENIÈRE-GRECO 2010. 
only few visible remains are preserved, nevertheless, we are dealing with a mythical site in several ways: the myth of its foundation by Jason; the cult of Hera which lasted centuries, with ritual practices that recall those of ancient Greece; the thrilling, heroic adventure of the first archaeological digs up to the most recent research; and the importance of the finds, from the mystery of the archaic metopes to the thousands of votive offerings found there.

The place shows all the characteristics of a locus sacer. The large waterway was probably full of marsh vegetation and formed a long and jagged lagoon. It experienced a long settlement history, from the archaic period through the Roman one, after the foundation of the Latin colony of Paestum in 273 BC. ${ }^{35}$

The votive offerings show the iconographic features of the goddess Hera, at the same time indicating which kind of rituals and religious ceremonies were celebrated there. Nevertheless, sometimes it could be very hard to understand the real meaning of the votive offerings due to their polysemous significance, depending on the different intentions of the devotees or on the many implications that a single ex-voto could have; moreover, especially during the Archaic period, the same kinds of votive offerings could have been related to several female deities because they presided over a similar range of cultural and religious spheres. In the case of the sanctuary of Hera at the mouth of the Sele river, however, on which the literary sources provide useful information about the main deity worship, the votive offerings system allows us to recognize the cult of Peloponnesian Hera. ${ }^{36}$

\subsection{The Archaic period}

During the archaic period, Hera seems to have many functions related to three different cultic spheres: fecundity/fertility, child rearing/initiation, marriage/childbirth.

The most ancient $e x$-votos date back to the early $6^{\text {th }}$ century BC: Corinthian pottery and some terracotta figurines. These show an ambiguous iconography because they could be related to various female deities and cults, but they had a specific and coherent significance within the Heraion at the mouth of the Sele river. These terracotta figurines represent an enthroned goddess holding a hand-modeled child in her arms, portraying Hera as a kourotrophos ${ }^{37}$ (fig. 5); the archetype of this iconography is recognizable in Corinth, and many examples were found in the Heraia of Argo and Perachora. ${ }^{38}$

In Poseidonia, this type of terracotta figurine is not present in the urban sanctuary of Hera, but only in peri-urban or extra-urban contexts; it also recurs in the sacred area of Santa Venera. ${ }^{39}$

35 ZanCANi-ZANOTti BiAnCo 1937, 206-354; ZANCANI-ZANOTti Bianco 1951-1954; LA GENIÈRE-GRECO 2010; GRECO 2012.

${ }^{36}$ GRECO 2010, 556-559; GRECO 2012, 177-179.

${ }^{37}$ These figurines were found in the so-called Corinthian layer, contemporary to the Ashes altar and related to the first period of frequentation of the sacred area during the first half of the $6^{\text {th }}$ century BC: GRECO 2012, 196, 229-230.

${ }^{38}$ GRECO 1998, 48-49, tav. VII; GRECO 2010, 550.

${ }^{39}$ AMMERMAN 2002, 84-85, n. 171, tav. XX. 
From the last decades of the $6^{\text {th }}$ century $\mathrm{BC}$ a great variety of terracotta types had a large circulation all over the Poseidonian sanctuaries. In this period the Sele votive terracottas are very similar to those found in the other Paestan sanctuaries; they replicate prototypes largely diffused in all the southern Italy Achaean colonies in the $6^{\text {th }}$ century BC.

A highly debated type represents a standing goddess wearing a high polos; her right arm is extended forward with a small hole in the hand in order to bear a spear ${ }^{40}$ (fig. 6). This iconography finds a close parallel in a standing female statuette from the

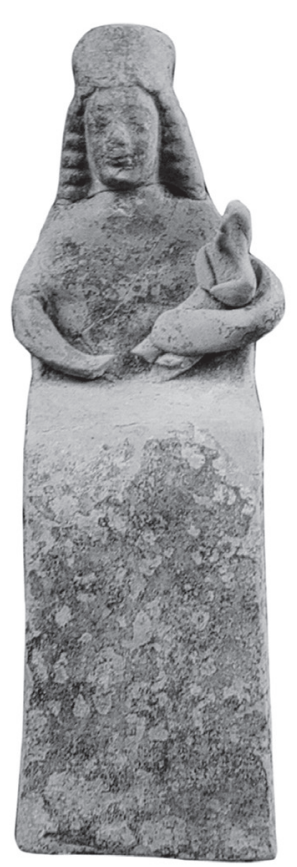

Fig. 5. The Corinthian type of kourotrophos. Poseidonia, the Foce Sele sanctuary of Hera. Early $6^{\text {th }}$ century BC (Department of Humanistic Studies - University of Naples Federico II)

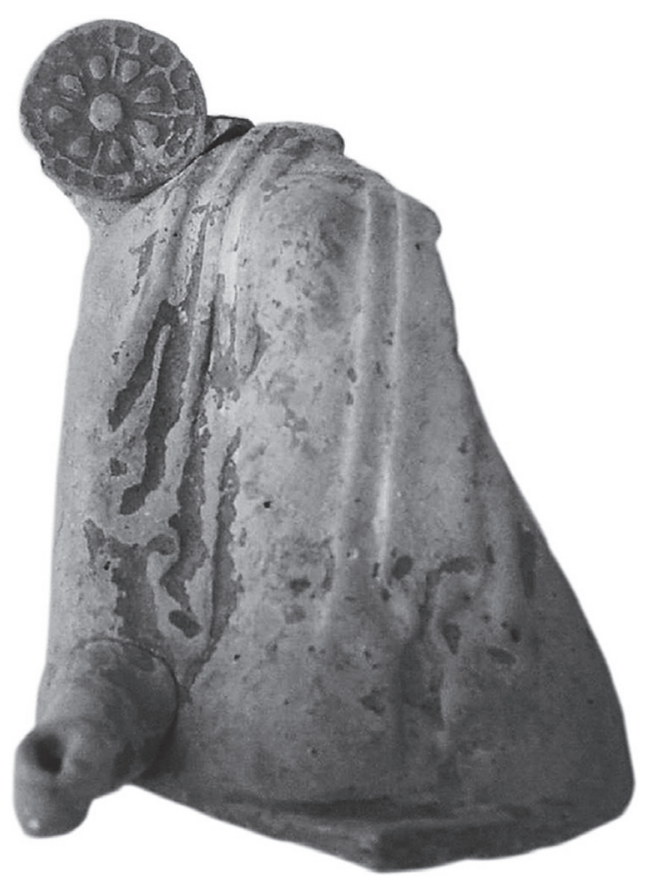

Fig. 6. Hera as an armed goddess. Poseidonia, the Foce Sele sanctuary of Hera, first half of the $6^{\text {th }}$ century BC

(Department of Humanistic Studies - University of Naples Federico II)

northern sanctuary of Poseidonia. The statuette from the urban northern sanctuary also represents an armed female deity, a typology recorded moreover in the Heraion of Metaponto, ${ }^{41}$ where the goddess wears a high and hollow polos; she has a flat body, her right arm is lifted up and flexed in order to bear a spear, while the left arm probably was holding a shield. ${ }^{42}$

${ }^{40}$ GRECO 2010, 562, fig. 195.

${ }^{41}$ OlbRich 1979, 158, tav. XXX, tipo A 124.

${ }^{42}$ CiPRIANI 1997, 217-218; CipRIANI 2008, 118-120, fig. 8; CipRIANI 2012, 40-41. 
This type can be referred to a typical sphere of influence of Hera during the Archaic period when Hera was worshipped not only as protectress of fecundity and motherhood, but also as a patron goddess of boys' and girls' initiation rites into adulthood. ${ }^{43}$

This role is also confirmed by presence of arms among votive offerings: at the sanctuary of Hera on the Sele river, some miniaturistic arrows were found as well as in the southern sanctuary of Poseidonia where many terracotta miniaturistic shields were also found. ${ }^{44}$ Equally conspicuous are the arms from the Persephoneion of Locri, where some armed standing-goddess statuettes, represented in the act of fighting as a promachos type, are also well-documented. ${ }^{45}$

Offering arms to Hera or Persephone is not surprising, nor was it unusual. Arms have a high symbolic value, closely related to the influence sphere or to the power scope of the goddess to whom arms were given. Paestan Hera, and also Locrian Persephone, were deities connected to natural-life cycles inasmuch as they were at the same time virgins, brides, mothers and warriors; so they ruled not only female rites of passage, preparing young girls for marriage, but all kinds of initiation rites, including male ones. In fact, the male passage into adulthood is marked by taking arms; for this reason the offerings of arms would have had a relevant meaning during the religious ceremonies related to these transitions in order to regain the favour of the goddess, also testifying one of the most important characteristics of Peloponnesian and Argive Hera. ${ }^{46}$

Some terracotta figurines date back to the second half of the $6^{\text {th }}$ century BC and they are strictly connected to the iconography of the armed goddess. These statuettes portray an enthroned goddess holding a hand-molded small animal that has been identified as a horse, representing the typical image of the so-called Hera Hippia.

The presence of the small horse does not identify Hera simply as a Potnia Theron but it does seem to underline her sovereign royal status. This aspect, related to the hoplosmia, also refers to male worshippers of Hera as the nurturer and patroness of warriors; Hera guaranteed that they would occupy and maintain a high social standing. From this point of view, the horse, usually considered as a symbol of regal power, could suggest that there probably were some horsemen among Hera devotees, such as the horsemen that raced in the Aspis games at the Heraion of Argo. This circumstance once again highlights the strong link between the Poseidonian Hera and the Peloponnese, particularly with Argo, Thebes, Perachora and Olympia, where Hera was also named Hippia. ${ }^{47}$

There is another notable object among the other ex-votos: a terracotta group of young girls holding one anothers'hands and forming a circle. It can be interpreted as a ritual dance, probably related once again to the rites of passage into adulthood. We

\footnotetext{
43 This cultic sphere is also highlighted by the inscription on an Archaic silver disk that confirms the function of Hera as the protectress of the arms and as patron of boys and girls initiation rites into adulthood: «Sacred to Hera. Make our bows stronger» (BIRASCHI 2012, 300-301).

${ }^{44}$ GiaCCO 2010, 674-675; GiaCCO 2015, 33-34; CiPRIANi 1997, 218, fig. 11.

${ }^{45}$ CARdosa 2002, 99-103. See also Brelich 1969, 225-227, 338-339; Giangiulio 1982, 5-69.

${ }^{46}$ Cipriani 1997, 218; GreCo 2010, 566-567.

${ }^{47}$ ARdovinO 1986, 113-117; CIPRIANI 1997, 218.
} 
find the same scene on curved metopes that decorated the late archaic temple. These metopes were variously interpreted. Paola Zancani gave the most convincing interpretation, recognizing the myth of Nereides and the kidnapping of Tethys. This myth implies one of the paradigms of Greek Archaic marriage that Hera supervised, and the choice to represent it through the images of Peleus and Tethys confirms that the Argonautic and Tessalic traditions were still alive in Poseidonia. ${ }^{48}$

At the end of the $6^{\text {th }}$ century BC, Hera loses some archaic features and her iconography begins to be fixed. One of the most common coroplastic votive offerings is the East Greek type of seated female figure. The goddess is hieratically seated on throne with her hands on her knees and her feet on a low stool. Her head is veiled; she wears a simple chiton and she is completely wrapped in a mantle. In the Heraion at the mouth of the Sele river, a large amount of the East Greek type figurines were found in the levels related to the construction of the Late Archaic temple, but the lack of any deity feature does not allow us to define the specific cultic identity of the goddess portrayed as a veiled adult lady (Teleia). This uncertain iconography could represent the goddess Hera or simply her devotees. ${ }^{49}$

In the same period a new type of kourotrophos is present. The East Greek type of the enthroned goddess is enriched by the addition of a baby on her left shoulder covered by the same veil as that of the goddess. It is quite difficult to identify the image as Hera or the representation of her devotees as well, as the previous Teleia type. ${ }^{50}$ This kourotrophos figurine is also recorded in the southern urban sanctuary, lasting until the Lucanian period. ${ }^{51}$

\subsection{The cult of Hera in the 5th century $B C$}

In the first half of the $5^{\text {th }}$ century BC Hera completely loses her archaic polymorphism and is worshipped as Teleia almost exclusively. In this period the votive terracottas reproduce the divine couple, with Hera seated beside Zeus as his bride ${ }^{52}$ (fig. 7). The god is bearded and half-naked with his legs covered by a mantle, while Hera is completely wrapped; she holds in her hand a plate full of fruit. They represent par excellence the divine couple that guaranteed the nuptial rites, who sealed the social bond of marriage through their own relationship. In this way the iconography of Hera is fixed as the bride of Zeus; she is worshipped as the patroness of the marriage and the social order, guaranteeing and preparing young girls for the marriage and for the oikos. ${ }^{53}$ This particular feature of the goddess is confirmed by the other kinds of offerings, all related to the mundus muliebris.

48 GreCo 2010, 569-570. Cf. also BuRKERT 2004.

49 The prototype is from the Eastern Greece; it begins to circulate in Western Greece during the last decades of the $6^{\text {th }}$ century BC when these terracotta figurines are also produced by local workshops: GRECO 2010, 568.

${ }^{50}$ GRECO 2010, 569-570, figs 203-204.

${ }^{51}$ CIPRIANI 1997, 219.

52 GRECO 1998, 49-61, fig. 19; GRECO 2010, 571-572, fig. 205.

53 Detienne 1975, 115. 


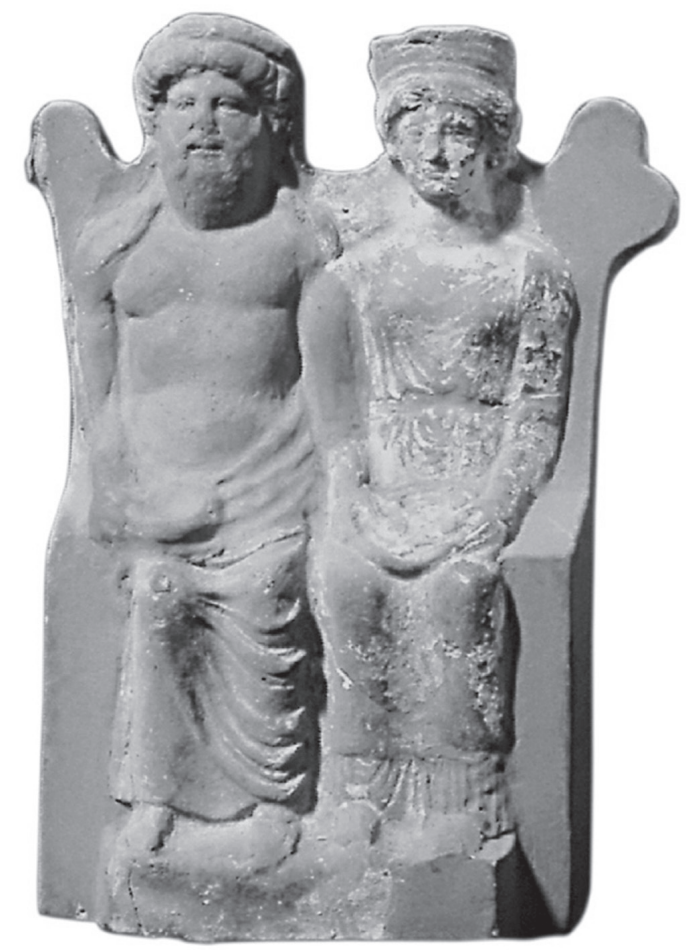

Fig. 7. Terracotta statuette representing Hera and Zeus enthroned. Poseidonia, the Foce Sele sanctuary of Hera, early $5^{\text {th }}$ century BC (Department of Humanistic Studies - University of Naples Federico II)

This type, representing the divine couple, is recorded in the Foce Sele sanctuary and in the southern urban one as well. ${ }^{54}$ It could be considered an original creation of the local workshop. Although similar statuettes are also present in the Greek Heraia (Samos, Rhodes, and Delos), the Poseidonian examples are easily recognizable because of both their typical and their particular features. ${ }^{55}$

\subsection{The Lucanian period}

At the end of the $5^{\text {th }}$ century BC, the arrival of Lucanians caused a change in the structure of the sanctuary, as exemplified through the construction of new buildings like the so-called Square building and the stoai in the north-eastern area of the sanctuary.

${ }^{54}$ Cipriani 1997, 219, fig. 13.

${ }^{55}$ GRECO 2010, 572. During the $5^{\text {th }}$ century BC the iconography of Hera is codified. The goddess is usually portrayed as an enthroned figure; she is completely wrapped in a mantle and wears the polos and the veil, shows a flower in the right hand while holds a phiale with the left hand. This is a generic image that we also find in many other Greek sanctuaries. Only at the end of the $5^{\text {th }}$ century BC the pomegranate symbol was added, creating the so-called Hera pestana recorded until the end of the $4^{\text {th }}$ century BC: GRECO 2010, 576-578, figs. 208-221. 
Behind the monumental altars and at about $80 \mathrm{~m}$ from the temple is a building with a perfectly square plan $(12 \times 12 \mathrm{~m})$, featuring a central room with no internal structures but with seven partitions at the middle of each wall used to subdivide the spaces. Built by the Lucanians with reused materials, it is dated between the end of the $5^{\text {th }}$ century BC and the early decades of the 4th century BC (fig. 8).

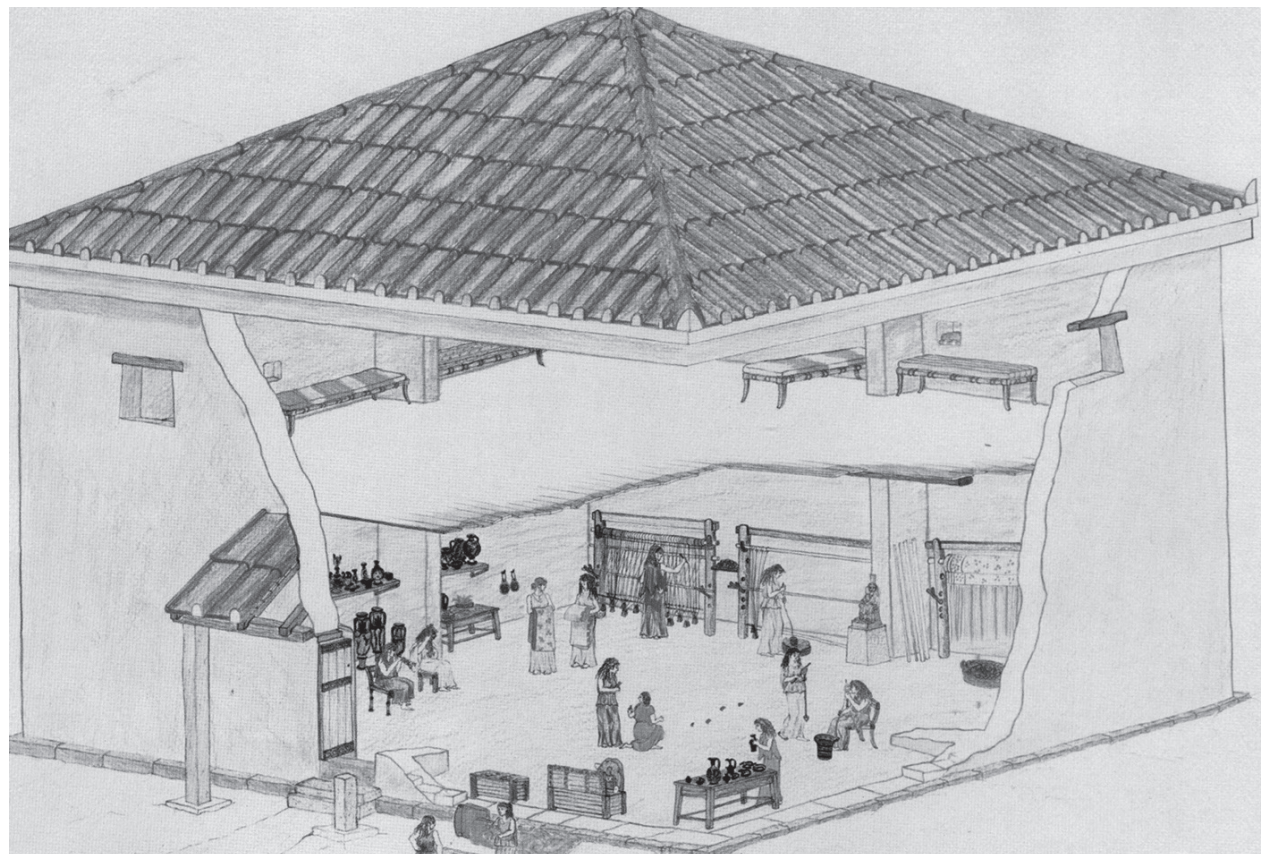

Fig. 8. The so-called Square building. Poseidonia, the Foce Sele sanctuary of Hera, hypothetical re-construction (Department of Humanistic Studies - University of Naples Federico II)

The building's possible functions continue to be a subject for debate, and its reconstruction here takes its cue from the finding of over 300 terracotta loom weights, which suggest a veritable activity of weaving the peplos for the goddess and clothing her statue for the procession on the occasion of the annual festivals was assigned to young girls of aristocratic families, who spent together their period of initiation in preparation for marriage. In fact, the mythography of Hera is characterized by recurrent ritual moments; one of these moments was the ritual bathing that re-established the virginity of the goddess. ${ }^{56}$ The ritual bathing took place after the disappearance of the goddess, who was made to become a virgin once again and ready for her marriage with Zeus. ${ }^{57}$ For this reason, dressing the Hera simulacrum was an essential part of the religious ritual, and the presence of aristocratic girls who lived far from their communities while weaving the clothes for Hera reminds us of the female initiation

${ }^{56}$ Paus. II 38. 2.

${ }^{57}$ CIRIO 1981, 136-142; GRECO 1995, 99. 
ceremonies related to the marriage. In this way, all the features of the mythography of Hera (disappearence/kidnapping, ritual bathing/virginity, dressing/marriage) are represented in the different stages of this rite in the adulthood. ${ }^{58}$

The objects found in the Square building are connected with the world of the female adolescent and with her prenuptial rites. They illustrate the various activities that were performed inside the building and testify to the complex being frequented chiefly by females. Pottery shapes mainly feature vases which explicitly concern marriage, with over 200 ointment jars, small, pyxides that complete the set of female toiletries. A group of ring vases (askoi), with their distinctive circular shape, of little functional use, reminds the ritual linked to female fertility. These vessels are a typical Paestan production; their shape is really complex and uncommon; probably they were produced for some élite customers and have a specific use. Probably they were used to contain ointments and perfumes that were believed to soothe the pains due to the childbirth, as do the many bronze and iron keys, which were votive offerings to the goddess so that she might alleviate the pains. ${ }^{59}$ The iron keys are recorded in many other female Greek sanctuaries such as the Heraia of Argo ${ }^{60}$ and Corinth $;{ }^{61}$ they are present in some Italic sanctuaries as well. ${ }^{62}$

The type of the kourotrophos is still attested during the $4^{\text {th }}$ century BC and it reminds us of the late archaic one, representing a seated female figure showing a veiled baby on her shoulder, but in this case, the iconography can be generically referred to a devotee. ${ }^{63}$

The coroplastic type knonw as Eileithyia is also recorded at the Sele sanctuary in this period. It represents a crouched female figure giving birth. Only two examples are persevered. The first one represents a crouched female figure that holds a dove in her right hand while she raises the mantle with the other hand. The figure does not present the typical features of a deity, and Langlotz had already excluded a relation to Hera. ${ }^{64}$ It is therefore possible to interpret this iconography as a general representation of a crouched woman giving birth. ${ }^{65}$ These images are really uncommon in the Greek sanctuaries, while they are quite frequent in many female sanctuaries in Magna Graecia, where people usually expressed their own concept of birth and maternity in a more

${ }^{58}$ GRECO 1995, 100.

${ }^{59}$ GRECO 2003, 103-122; FERRARA 2013.

${ }^{60}$ CHASE-WALDSTEIN 1905, tav. CXXXIII.

${ }^{61}$ NewAll StilWELL-BENSON 1946-1948, tav. 50.

${ }^{62}$ In the sanctuary of the dea Marica at the mouth of the Garigliano river (MINGAZZINI 1938, 941), and in the sacred areas of Garaguso or Colla di Rivello (GRECO 1982, 56) where probably the keys had the same ritual meaning.

${ }^{63}$ GRECO 2010, 578-579.

${ }^{64}$ LANGLOTZ 1968, 298-299.

${ }^{65} \mathrm{~A}$ brand new type are some floreal figurines, so-called donna-fiore, for a long time considered as concrete image of Hera worshipped in quality of Antheia, but probably they were simply thymiateria, used as incense burners: CANTONE 2015. During the $4^{\text {th }}$ century BC the terracotta figurines representing devotees became more numerous than the images of the goddess. Hera, generally portrayed following the type of the so-called Hera pestana that had a clear funeral valence: she was represented wrapped in a cloak with her head covered and a veil, seated on a throne, with her attributes being the pomegranate, her staff or a basket of fruit. 
explicit and physical way than the Motherland Greek people were used to doing. ${ }^{66}$ These ex votos from the Sele sanctuary can be considered as an original creation due to a specific request of some devotees who intended to highlight the protecting role of Hera just in the moment of childbirth as a sign of their thanksgiving.

During the Roman period, in the $2^{\text {nd }}$ century BC, some votive wombs clearly indicate a remarkable continuity of worship practice, reminding us once again of the role of Hera's connection to fecundity and motherhood, but in a cultural framework deeply changed, showing many parallels with some italic votive deposits.

\section{HERA, MARRIAGE, AND CHILDBIRTH IN MAGNA GRAECIA: THE COROPLASTIC EVIDENCE (C.M.M.)}

Analyses of the finds from the bothroi and stratigraphy in the sanctuaries dedicated to Hera in the three large southern Italian Achaean colonies (Poseidonia, Croton/Capo Lacinio and Metapontum), attest to the presence of a series of cults with female participants, which required offerings of different types of votive objects, datable to a period between the $6^{\text {th }}$ and $4^{\text {th }}$ centuries BC. The coroplastics are among the most distinctive of them, and show the goddess in various poses (with or without attributes) which we will describe below, along with fruits, doves, and wombs that are an evident reference to her role as the guarantor of fertility. Such archaeological evidence, along with that from the ancient sources, demonstrates the presence of cults centered on fertility and performed under Hera's protection. In her quality as goddess-bride par excellence, she protected the prescribed and institutionalized relationship between the two sexes, assuming the protection of marriage, of which she was said to be the "keeper of the keys" and of all the subsequent events which ensued after marriage.

Statuettes of Hera and Zeus seated on a single throne deriving from $5^{\text {th }}$ century $\mathrm{BC}$ models also refer to the sacred conjugal union (see fig. 7, on p. 348). ${ }^{67}$ Zeus is bearded, his torso naked and his legs covered by the himation and Hera is wearing a polos, holding a dish of fruit on her lap. They are Hera Teleia and Zeus Teleios also known as "Lords of the House", the couple which protects the conjugal union and which, through the religious ceremonies sanctioning the marriage, acts as a guarantor of the marriage rituals, and, by giving its consent, seals the full validity of a marriage within the society. Therefore, young brides-to-be invoked the goddess by offering statuettes of this divine couple as ex-votos, placing themselves under their protection. This practice is also confirmed by the nuptial lebes made by the pottery painter Assteas, showing the judgment of Paris in the presence of Hera (the other goddesses are excluded) and Hermes, and offered by a bride-to-be at the Heraion located at the mouth of the Sele river.

\footnotetext{
${ }^{66}$ PEDRUCCI 2013, 119-123.

${ }^{67}$ CIPRIANI 1997, with previous bibliography. For the coroplastic evidence of Poseidonia, see above the contribution of Marialucia Giacco.
} 
Ancient sources speak, about rituals connected with marriage carried out under the aegis of the goddess at various Greek sites (Argos, Athens, Platea, Samos, etc.), which included ritual bathing, preparation of the marriage bed, a procession, sacrifices, and games in her honour. It can certainly be imagined that such ceremonies took place also in southern Italian sanctuaries dedicated to Hera. ${ }^{68}$ This is suggested by several fragments from a frieze found at Metapontum showing a wedding procession, the bride and groom seated on a horse-drawn cart preceded by a group of young girls, which clearly recalls the celebration of the hieros gamos of Hera and Zeus at Samos. ${ }^{69}$ Furthermore, with regard to young girls, the suggestion that Hera played a determinant role in the transition from the juvenile state to that of adulthood can be seen within her myth that constantly refers to her early role firstly in the sphere of youth and the later one in the mature age of a woman as wife and mother. A large amount of archaeological evidence connected with rites of passage has been found in the Heraia of the ancient world. ${ }^{70}$ Even though the central element was later to become increasingly connected to the gamos, there is nevertheless evidence of many elements defining earlier rites of initiation, from the weaving of the peplos for the goddess to the offering of elements of personal clothing. ${ }^{71}$

Although Hera is the guarantor, together with Zeus, of legitimate marriage, according to myth she does not preside over the process of procreation, which is the union's definitive aim. She appears as a bride and protectress of the marriage, but only in as far as she represents the fulfilment - telos - and highlight of feminine existence until the moment of procreation. She is precluded from the direct function of maternity, to the point that her extraneousness from the maternal sphere is at times affirmed. The reason for this ought to be sought in the fact that she belongs to an eminently Archaic typology of female deities (like Artemis and Athena), characterized by the indistinct nature of their spheres of action or, to be more precise, by their polyvalence, and yet differing from that which the same goddesses characterized in the Classical Olympic pantheon.

Archaeological evidence, however, testifies to the moments of birth and growth and the perpetuation of the polis that are the occasion for religious practices in honour of Hera. In particular, assistance during childbirth is attested by iron votive keys, ${ }^{72}$ present in Poseidonia both in the southern sanctuary and in the Heraion on the river Sele, and interpreted as ex-voto offerings, with reference to their function, in the hope of an easy childbirth. In this sense, the sources tell of frequent invocations to the goddess, both as Hera and as her epiclesis Eileithyia, to protect the future mother in the difficult time of childbirth or as thanksgiving for a happy outcome of the event. In this regard an epigram by Callimachus ${ }^{73}$ can be cited in which the mother-to-be Lykainis invokes Eileithyia "propitiator of births" to relieve the labour pains, and she promises the goddess a rich gift to encourage her to bestow on her the favour of bearing a son.

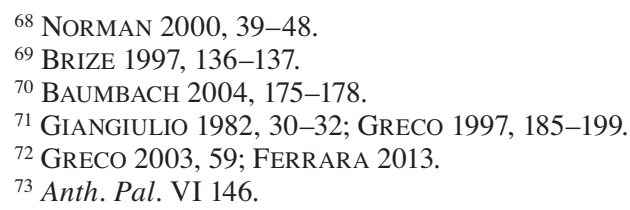


In a fragment of the Argolika by Derkylos, datable to between the $4^{\text {th }}$ and $3^{\text {rd }}$ centuries BC, in the context of a description of the loutra (bath) of Hera Akraia, there is mention of a college of virgin priestesses, the Locheutriai, who were in charge of supplying water when the gynaikes dmoides gave birth. ${ }^{74}$ Therefore at Argos the protection guaranteed by Hera to mothers-to-be was not reserved exclusively to free women but also to slaves. ${ }^{75}$ This may also have been the case of cults at Capo Lacinio, where the presence of votives gifts to Hera attesting gratitude for the acquisition or recovery of freedom could hint at a similar practice. ${ }^{76}$ Lastly, terracottas of Hera/Eileithyia have been found at Poseidonia in the sanctuary of Sele, where she is represented naked and kneeling in the birthing position: these statuettes were produced between the final decades of the $4^{\text {th }}$ century BC until the end of the Hellenistic period (fig. 9). ${ }^{77}$

As we have seen, the goddess presents a specific relationship with diverse moments in the life and activity of a woman. In addition to being connected with

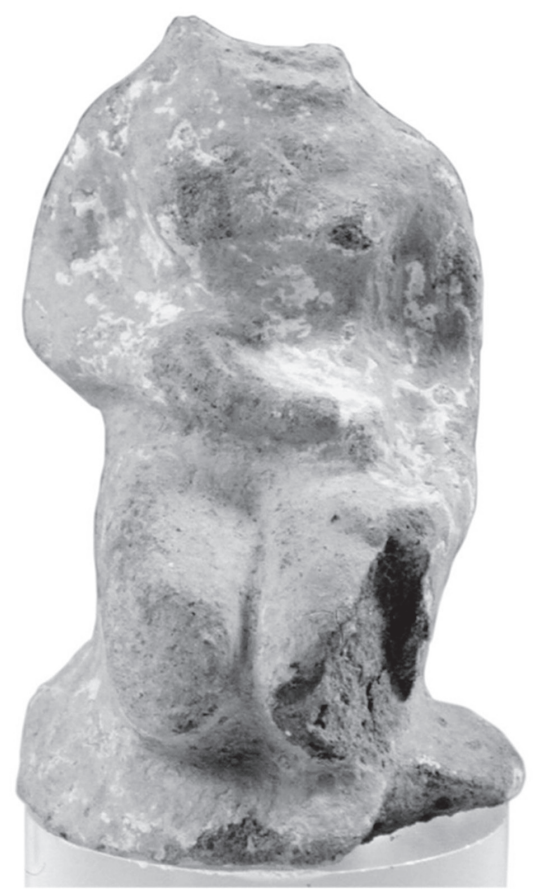

Fig. 9. The Eileithyia coroplastic type. Poseidonia, the Foce Sele sanctuary of Hera, $4^{\text {th }}$ century BC (Department of Humanistic Studies - University of Naples Federico II)

\footnotetext{
${ }^{74}$ HadZisteliou Price 1978, 145.

75 BAUMBACH 2009, 203-233.

${ }^{76}$ GiangiUlio 1982, 18-19.

${ }^{77}$ Dewailly 1997, 203; BaUmbaCH 2009, 136-137.
} 
childbirth, she also shows a particular relationship with the upbringing of children. ${ }^{78}$ If on the one hand there are no attestations of Hera with the epiclesis of kourotrophos and her link with childbirth is instead provided by the epiclesis Eileithyia, as documented by Esichio/Hesychius at Argos, on the other hand the local cultic aspects recall a different aspect. Her kourotrophic attribute is well-attested by a series of terracotta ex-votos showing the veiled goddess seated on a throne with a baby in her arms, in an iconography typical of the Paestum area. In these representations, the goddess does not exhibit the baby as the fruit of a divine birth. It is rather the incarnation of legitimate offspring, born from a marriage consecrated by the divine couple, in which Hera, ensuring in some senses nourishment, and in others protection, guarantees the growth of the baby and therefore the perpetuation of the local population.

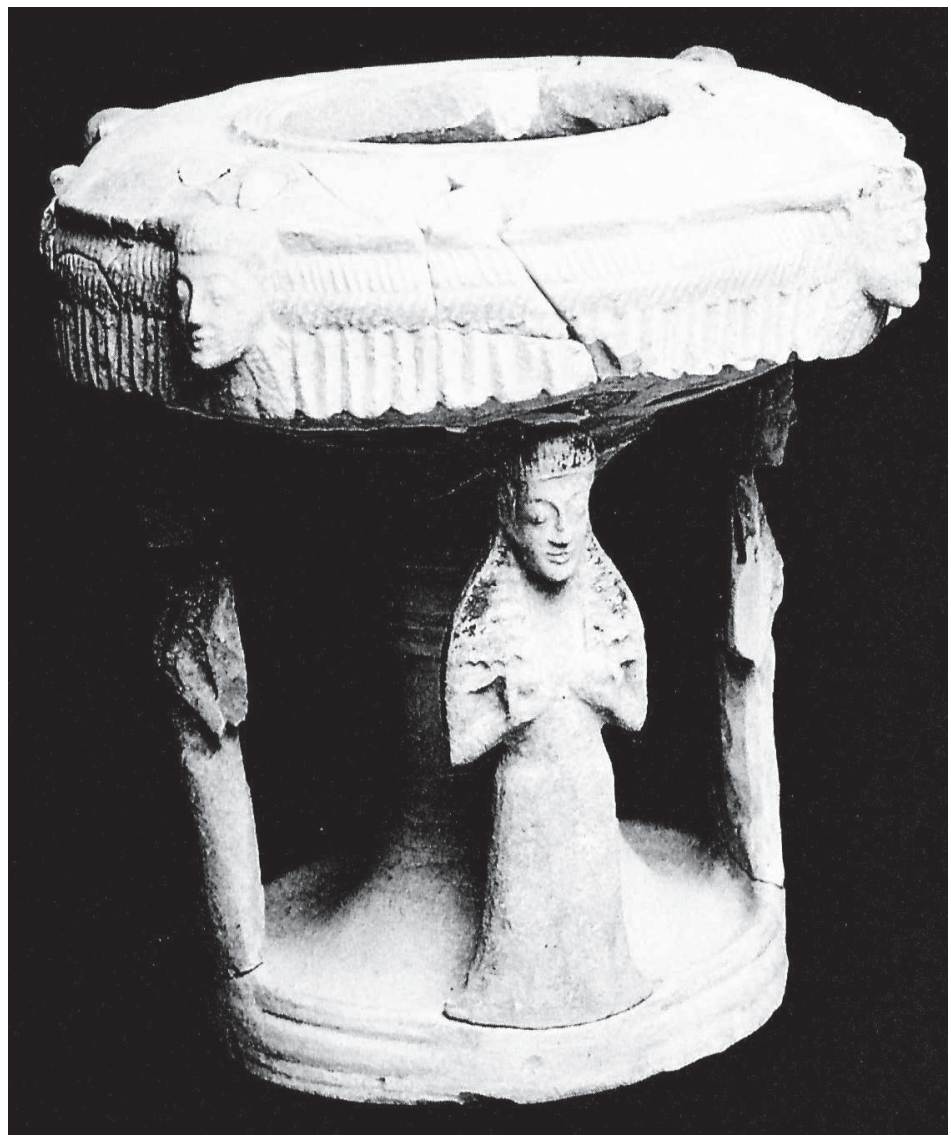

Fig. 10. Terracotta lamp adorned with four standing female figures, that are holding their breasts in the hands. Poseidonia, the Foce Sele sanctuary of Hera, $6^{\text {th }}$ century BC

${ }^{78}$ HADZISTELIOU PRICE 1978, 193. 
At Poseidonia, statuettes of Hera in the attitude of kourotrophos are attested for the Archaic period and in the $5^{\text {th }}$ century BC (see fig. 5, on p. 345), ${ }^{79}$ while there is no evidence in published material for this specific iconography at Capo Lacinio and Metapontum in the same period. Furthermore, it must be stressed that the Archaic examples from Poseidonia did not originate series or copies, but rather that here (as at Perachora, Argos, and Corinth), the iconography of the kourotrophos disappears completely during the $6^{\text {th }}$ century BC, only to reappear around the mid $-5^{\text {th }}$ century BC with the same typology but in a radically changed cultic system.

For the Archaic levels, a type of statuette, well attested at Poseidonia and Capo Lacinio, representing a standing female figure with her hands to her breasts, provides a more evocative reading.

In 1910, during excavations at Capo Colonna, P. Orsi found three small headless terracotta female figurines with both hands clutching the breasts, datable to the first decades of the $6^{\text {th }}$ century BC.$^{80}$ Later, P. Zancani published a small votive lamp ${ }^{81}$ from the Heraion at Sele and stated that the four standing female figures supporting the bowl of the lamp and represented as holding their breasts in their hands (fig. 10), were made by the same atelier as the one who made the statuettes from Crotone. ${ }^{82}$ The offering to the goddess of a representation of the act of breastfeeding ought then to be taken as the expression of a clear relationship of protection and patronage existing between Hera and mothers. C. Sabbione has convincingly located the production of this class of objects at Croton and investigated its distribution area. ${ }^{83}$ Above all, what it is important to highlight here is the origin of this iconographic type, which is documented in the Archaic period mainly in the Peloponnese and in the Achaean colonies of Magna Graecia. The clear emphasis given to the breasts has suggested a possible link with the Eileithyia of Argos in her role of protectress of childbirth as narrated by Pausanias. ${ }^{84}$

\section{CONCLUSIONS (M.G.)}

This brief examination of the material evidence has focused on some aspects of the cult of Hera. The result will perhaps help in defining them better than has been done hitherto. The Achaean Hera presents the typical characteristics of an important local deity, capable of regulating some very important features of the social structure, and tending to assume the universal traits of a protectress of all the aspects of human life.

In Poseidonia-Paestum and at the sanctuary at the mouth of the Sele river, the goddess Hera had many different features not only specifically related to the motherhood during the long life of the sanctuary.

\footnotetext{
${ }^{79}$ HAdZISTEliou PRICE 1978, 179-181; BAUMBACH 2009, 136-137.

${ }^{80}$ ORSI 1911.

${ }^{81}$ ZANCANI 1960, 69-77.

${ }^{82}$ GiAnGIULIO 1982, 25-26.

${ }^{83}$ SABBIONE 1994, 245-301, 272-273; SPADEA 1994, 10, fig. 10.

${ }^{84}$ Paus. II 22. 6.
} 
In the Archaic period, the goddess Hera was worshipped as the protectress of fertility, but also as a girl and an armed virgin. According to her kourotrophic role, she presided over the rites of passage into adulthood as it is recorded in the main Peloponnesian Heraia of Argo and Perachora in the same period.

A fundamental role is played by the function of guarantor, together with Zeus, of the pact of legitimate matrimony, of protecting and raising the children born from this union and, by extension, the forthcoming society as a whole. These aspects would become recognizable in the iconography, as we have seen, through a process of transformation that took place between the mid- $6^{\text {th }}$ century BC and the $5^{\text {th }}$ century $\mathrm{BC}$, and was to lead to the clearest definition of the goddess as wife/adult/Teleia.

In Poseidonia, during the $5^{\text {th }}$ century $\mathrm{BC}$ her bond with fecundity and with marriage was emphasized. Some terracotta statuettes representing Zeus and Hera enthroned remind us of the mythical and ritual archetype of the monogamous marriage. ${ }^{85}$ But if Hera was the patroness of the "right" marriage, she did not guarantee the procreation that was one of the main purposes of the marriage itself. Only Demetra and Kore guaranteed the kalligeneia. From this point of view, Hera was not directly connected with motherhood (in a strictly "biological" sense, even though she has a crucial role in the legitimation of illegitimate offspring, as Giulia Pedrucci has argued in her paper) and in fact, in some minor variant she is described as childless. Anyway Hera is strictly related both to the birth and the growth that were essential to the telos and to the survival of the polis.

As well as in Poseidonia, Hera's attributes linked to marriage became definitively prevalent in the Classical period in the other Achaean colonies in Magna Graecia, where Hera lost her dual aspect and the attribute of warrior goddess was taken on by Athena. Kroton, however, the available documentation from Capo Lacinio suggests that Hera continued to be worshipÍped as a warrior, a virgin, and a kourotrophos for a long time, extending her universal patronage across the entire sphere of human life and of nature, continuing the legacy from the late Archaic period.

The Hellenistic terracotta figurines representing the Eileithyia type from the sanctuary of Hera at the mouth of the Sele river highlight the protection of the goddess during labour as well as the iron keys that were offered to the goddess in the hope of soothing the pains. ${ }^{86}$ Hera also has the function of kourotrophos, but the goddess is never characterised as a "mother", even though the child can be only interpreted as a symbol of the offspring that a legitimated marriage, consecrated by Zeus and Hera, should guarantee. Hera only assured nourishment and protection, allowing the perpetuation and preservation of the Poseidonian civic body.

\author{
Marialucia Giacco \\ University of Naples Federico II \\ Chiara Maria Marchetti \\ University of Verona \\ ${ }^{85}$ DetienNe 1975, p. 115. \\ ${ }^{86}$ Cipriani 2012, 219; GReCO 2003; GRECO 2010, 581; GRECO 2012.
}




\section{BIBLIOGRAPHY}

Ammerman, R. M. 2002: The Sanctuary of Santa Venera at Paestum II. The Votive Terracottas. Ann Arbor

Ardovino, A. M. 1986: I culti di Paestum antica e del suo territorio. Napoli

BAUMBACH, J. D. 2004: The Significance of Votive Offerings in Selected Hera Sanctuaries in the Peloponnese, Ionia and Western Greece [BAR International Series 1249]. Oxford

Baumbach, J. D. 2009: Speak, votives... Dedicatory Practice in Sanctuaries of Hera. In Prêtre, C. (éd.): Le donateur, l'offrande et la déesse. Systèmes votifs dans les sanctuaires de déesse du monde grec. Actes du 31 colloque international organisée par l'URM Halma-Ipel (Université Charles-de-Gaulle/Lille 3, 13-15 décembre 2007) [Kernos suppl. 23]. Liège, pp. 203-223.

BINDER, G. 1976: Geburt II (religions-geschichtlich). In Reallexikon für Antike und Christentum, cc. 43-171.

BIRASCHI, A. M. 2012: La documentazione letteraria ed epigrafica. In Biraschi, A. M. - Cipriani, M. - Greco, G. - Taliercio Mensitieri, M. (ed.): Culti greci in Occidente. III: Poseidonia-Paestum. Taranto, pp. 300-301.

BÖHM, S. 1990: Die nackte Göttin: zur Ikonographie und Deutung unbekleideter weiblicher Figuren in der frühgriechischen Kunst. Mainz

BRELICH, A. 1969: Paides e parthenoi. Roma

BRIZE, P. 1997: Offrandes de l'époque géometrique er archaïque à l'Heraion de Samos. In La Genière, J. de (éd): Héra. Images, espaces, cultes. Actes du Colloque International du Centre de recherches Archéologiques de l'Université de Lille III et de l'Association P.R.A.C. (Lille, 29-30 novembre 1993). Naples, pp. 123-139.

BURKERT, W. 2004: Initiation. In Thesaurus Cultus et Rituum Antiquorum. Lexikon antiker Kulte und Riten. Bd. I. Oxford-Los Angeles, s.v.

CAntone, C. 2015: La "donna-fiore" nel santuario di Hera alla foce del Sele. Un progetto per l'informatizzazione dei dati. Pozzuoli

CARdosA, M. 2002: I doni di armi nei santuari delle divinità femminili in Magna Grecia. In Rubinich, M. (a cura di): Le arti di Efesto: Capolavori in metallo dalla Magna Grecia; catalogo della Mostra (Trieste, 8 marzo-28 luglio 2002). Milano, pp. 99-103.

Chase, G. H. - Waldstein, C. 1905: The Argive Heraeum. Vol. II: Terra-cotta figurines, terra-cotta reliefs, vases, vase fragments, bronzes, engraved stones, gems and ivories, coins, Egyptian or Graeco-Egyptian objects. Boston

CipRIANI, M. 1997: Il ruolo di Hera nel santuario meridionale di Poseidonia. In La Genière, J. de (éd.): Héra. Images, espaces, cultes. Actes du Colloque International du Centre de recherches Archéologiques de l'Université de Lille III et de l'Association P.R.A.C. (Lille, 29-30 novembre 1993). Naples, pp. 211-225.

Cipriani, M. 2008: Il santuario settentrionale di Poseidonia: la documentazione archeologica dei culti dalla fondazione della città al tramonto dell'egemonia lucana. In Greco, G. - Ferrara, B. (a cura di): Doni agli Dei. Il sistema dei doni votivi nei santuari. Atti del Seminario (Napoli, 21 aprile 2006). Napoli, pp. 113-139. 
CiPRIANI, M. 2012: Le testimonianze in città e nel territorio. In Biraschi, A. M. Cipriani, M. - Greco, G. - Taliercio Mensitieri, M. (a cura di): Culti greci in Occidente, III. Poseidonia-Paestum. Taranto, pp. 27-169.

Cirio, A. M. 1981: La dea Parthenos di Samo. Bollettino Classico 3, pp. 136-142.

Clark, I. 1998: The gamos of Hera. Myth and Ritual. In Blundell, S. - Williamson, M. (eds): The Sacred and the Feminine in Ancient Greece. London-New York, pp. 13-26.

DETIENNE, M. 1975: I giardini di Adone. Torino

DEWAILly, M. 1997: L'Héraion de Foce del Sele: Quelques aspects du culte d'Héra à l'époque hellénistique d'après les terres cuites. In La Genière, J. de (éd.): Héra. Images, espaces, cultes. Actes du Colloque International du Centre de recherches Archéologiques de l'Université de Lille III et de l'Association P.R.A.C. (Lille, 29-30 novembre 1993). Naples, pp. 201-210.

Dunbabin, T. J. (ed.) 1962: Perachora: The Sanctuaries of Hera Akraia and Limenia. Excavations of the British School of Archaeology at Athens 1930-1933. Vol. II: Pottery, ivories, scarabs, and other objects from the votive deposit of Hera Limenia. Oxford

FERRARA, B. 2013: Il santuario di Hera alla foce del Sele. La ceramica a vernice nera. $2^{\text {a }}$ ed., Pozzuoli

GiAcCO, M. 2010: I bronzi. In La Genière, J. de - Greco, G. (a cura di): Il santuario di Hera alla foce del Sele. Indagini e studi 1987-2006 [Atti e Memorie della Società Magna Grecia, serie IV]. Roma, pp. 665-684.

GiAcCO, M. 2015: Votive Bronze Objects from the Sanctuary of Hera at the Mouth of the Sele River (Paestum). In Deschler-Erb, E. - Della Casa, Ph. (eds): New Researches in Ancient Bronzes. Acta of the XVIIIth International Congress on Ancient Bronzes, Zürich 2013. Zürich, pp. 29-38.

GiangiUlio, M. 1982: Per la storia dei culti di Crotone: il santuario di Hera lacinia. Strutture e funzioni cultuali, origini storiche e mitiche. Archivio Storico per la Calabria e la Lucania 49, pp. 5-69.

GreCO, G. 1982: L'evidenza archeologica nel Lagonegrese. Catalogo della Mostra documentaria (Rivello, Cripta di San Nicola, 13 giugno 1981). Matera

Greco, G. 1995: Kosmos thes theou. In Cerasuolo, S. (a cura di): Mathesis e Philia. Studi in onore di Marcello Gigante. Napoli, pp. 87-107.

Greco, G. 1997: Des étoffes pour Héra. In La Genière, J. de (éd.): Héra. Images, espaces, cultes. Actes du Colloque International du Centre de recherches Archéologiques de l'Université de Lille III et de l'Association P.R.A.C. (Lille, 29-30 novembre 1993). Naples, pp. 185-199.

Greco, G. 1998: Da Hera Argiva ad Hera Paestana. In Greco, G. - Adamo Muscettola, S. (a cura di): I culti della Campania antica, Atti del Convegno Internazionale in ricordo di Nazarena Valenza Mele, Napoli, 1995. Roma, 45-62.

Greco, G. 2003: Heraion alla foce del Sele: nuove letture. In De Cazanove, O. Scheid, J. (éd.): Sanctuaires et sources. Les sources documentaires et leurs limites dans la description des lieux de culte. Actes de la table ronde (Naples 2001). Napoli, pp. 103-122. 
GRECO, G. 2010: Il culto, il rito, i doni votivi. La fenomenologia religiosa dall'universo olimpico a quello ctonio. In La Genière, J. de - Greco, G. (a cura di): Il santuario di Hera alla foce del Sele. Indagini e studi 1987-2006. Roma, pp. 555-592.

GRECO, G. 2012: Il santuario di Hera alla foce del Sele. In Biraschi, A. M. - Cipriani, M. - Greco, G. - Taliercio Mensitieri, M. (a cura di): Culti greci in Occidente. III: Poseidonia-Paestum. Taranto, pp. 171-246.

HAdZisteliou Price, T. 1978: Kourotrophos. Cult and Representations of the Greek Nursing Deities. Leiden

JEnkins, R. J. H. 1931-1932: Archaic Argive Terracotta Figurines to 525 BC [The Annual of the British School at Athens 32]

KILIAN-DiRLMEIER, I. 1985: Fremde Weihungen in griechischen Heiligtümern vom 8. bis zum Beginn des 7. Jahrhunderts v. Chr. Jahrbuch des Römisch-Germanischen Zentralmuseums 32, pp. 215-254.

LA GENIÈRE, J. DE - GRECO, G. (a cura di) 2010: Il santuario di Hera alla foce del Sele. Indagini e studi 1987-2006 [Atti e Memorie della Societa Magna Grecia, serie IV]. Roma

LANGLOTZ, E. 1968: L'arte della Magna Grecia. Arte greca in Italia meridionale e Sicilia. Roma

MASSERIA, C. - TORELLI, M. 1999: Il mito all'alba di una colonia greca. Il programma figurativo delle metope dell'Heraion alla Foce del Sele. In Massa-Pairault, Fr.-H. (dir.): Le Mythe grec dans l'Italie antique. Fonction et image. Actes du Colloque international organisé par l'École française de Rome, l'Istituto italiano per gli Studi filosofici (Naples) et L'UMR du CNRS (Archéologies d'Orient et d'Occident), Rome, 14-16. novembre 1996. Roma, pp. 205-262.

Mele, A. 1992: Intervento. In Stazio, A - Ceccoli, St. (a cura di): Poseidonia-Paestum, Atti del XXVII Convegno di Studi sulla Magna Grecia (Taranto-Paestum, 9-15. ottobre 1987). Taranto, pp. 618-621.

Morgan, C. A. 1999: Isthmia, VIII. The Late Bronze Age Settlement and Early Iron Age Sanctuary. Princeton

MingAZZINI, P. 1938: Il santuario della dea Marica alle foci del Garigliano. Monumenti antichi: pubblicati per cura della R. Accademia dei lincei. 37, cc. 693-984.

Newall Stilwell, A. - Benson, L. 1946-1948: Corinth XV, 1-3. The Potters Quarter: the Pottery. Princeton, NJ

Norman, N. J. 2000: Hera, hieros gamos and the chora of Poseidonia. In Holloway, R. R. (ed.): Miscellanea Mediterranea. Providence, pp. 39-48.

OlBRICH, G. 1979: Archaische Statuetten eines Metapontiner Heiligtums. Roma

ORSI, P. 1911: Scavi nel santuario di Hera Lacinia a Crotone-Capo Colonna. Notizie degli Scavi, Suppl. pp. 77-124.

PAYNe, H. (ed.) 1940: Perachora: the sanctuaries of Hera Akraia and Limenia. Excavations of the British School of Archaeology at Athens, 1930-1933. Oxford

PEDRUCCI, G. 2013: L'allattamento nella Grecia arcaica e classica. Roma

Pirenne-Delforge V. - Pironti G. 2009: La féminité des déesses à l'épreuve des épiclèses: le cas d'Héra. In Bodiou, L. - Mehl, V. (éds.): La religion des femmes en Grèce ancienne. Mythes, cultes et société. Rennes, pp. 95-109. 
Pirenne-Delforge, V. - PIRONTI, G. 2014: Héra et Zeus à Lesbos: entre poésie lyrique et décret civique. Zeitschrift für Papyrologie und Epigraphik 191, pp. 27-31.

Pirenne-Delforge, V. - Pironti, G. 2015: Héra et les enfants de Zeus. In Belayche, N. - Pirenne-Delforge, V.: Fabriquer du divin. Liège, pp. 41-57.

ProvenZA, A. 2010-2011: Gli Heraia di Olimpia e le donne di Elide. Riti di passaggio e inni tra Era e Dioniso. In Castaldo, D. - Giannachi, F. G. - Manieri, A. (a cura di): Poesia, musica e agoni nella Grecia antica. Atti del IV Convegno internazionale di MOI $\Sigma$ A. Lecce, pp. 99-121.

SAbBione, C. 1994: L'artigianato artistico. In Stazio, A. - Ceccoli, St.: Crotone. Atti del XXIII Convegno Internazionale di Studi sulla Magna Grecia (Taranto, Crotone, 1983). Taranto, pp. 245-301.

SAlviAT, F. 1964: Les Théogamies attiques, Zeus Téleios et l'Agamennon d'Eschyle. Bulletin de correspondance hellénique 88, pp. 652-654.

SCHLESIER, R. 2002: Heimliche Liebe im Zeichen der Mysterien. Verschleierung und Enthüllung in Euripides' 'Hippolytos'. In Klinger, E. - Böhm, St. Franz, Th. (Hg.): Paare in antiken religiösen Texten und Bildern. Symbole für Geschlechterrollen damals und heute. Würzburg, pp. 51-91.

SPADEA, R. 1994: Il tesoro di Hera. Bollettino d'Arte 88, pp. 1-34.

STOOP, M. W. 1960: Floral Figurines from South Italy. Assen

STRøM, I. 1988: The Early Sanctuary of the Argive Heraion and Its External Relations, $8^{\text {th }}$-early $6^{\text {th }}$ Century BC. The Monumental Architecture. Acta Archaeologica 59, pp. 173-203.

WeBB, V. 1978: Archaic Greek Faience: Miniature Scent and Related Objects from East Greece, 650-500 BC. Warminster

ZANCANI, P. 1960: Lampada arcaica dallo Heraion alla Foce del Sele. Atti e Memorie della Società Magna Grecia 1, pp. 69-77.

ZANCANI, P. - ZANOTTI BiAnco, U. 1937: Capaccio. Heraion alla foce del Sele (Relazione preliminare). Notizie degli Scavi 62, pp. 206-254.

ZANCANI, P. - ZANOTTI BIANCO, U. 1951-1954: Heraion alla foce del Sele. I-II. Roma 